\title{
Treatment of acquired flexural deformity of the distal interphalangeal joint in the horse: a retrospective study of 51 cases
}

\author{
Behandeling van verworven retractie van de diepe buigpees bij het paard: \\ een retrospectieve studie van 51 gevallen
}

\section{S. Carlier, M. Oosterlinck, A. Martens, F. Pille}

Department of Surgery and Anesthesiology of Domestic Animals, Faculty of Veterinary Medicine, Ghent University, Salisburylaan 133, B-9820 Merelbeke, Belgium

Frederik.Pille@ugent.be

$\Lambda_{\text {bstract }}$

Flexural deformity of the distal interphalangeal joint is an important disorder in horses, which can be acquired during the first year of life, often as a result of lateralization during grazing. In this retrospective study, the medical files of 51 cases presented at the Faculty of Veterinary Medicine of Ghent University (1999-2013) were analyzed, followed by a telephone questionnaire. In $65 \%$ of the conservatively treated patients, the hoof conformation corrected completely, which was not significantly different from what was seen in the surgically treated group (complete correction in $56 \%$ of cases). Foals treated conservatively before the age of six months and foals treated surgically before twelve months of age, had a significantly better chance of a successful correction than older foals. Moreover, cases in which treatment did not restore the hoof conformation completely, presented a significantly higher chance of (persisting) lameness and were significantly less likely to have an athletic career. Finally, this study proved a significant association between the hoof conformation of the dam and her foals.

\section{SAMENVATTING}

Retractie van de diepe buigpees is een belangrijke aandoening die veulens gedurende hun eerste levensjaar kunnen verwerven ten gevolge van lateralisatie bij het grazen. In deze retrospectieve studie werden de medische dossiers geanalyseerd van 51 gevallen die behandeld werden aan de Faculteit Diergeneeskunde van de Universiteit Gent tussen 1999 en 2013. Deze analyse werd gevolgd door een telefonische enquête. Bij $65 \%$ van de conservatief behandelde dieren normaliseerde de hoefconformatie volledig, wat niet significant verschillend bleek van het percentage paarden dat een volledig herstel kende na een chirurgische behandeling (56\%). Veulens die vóór de leeftijd van zes maanden een conservatieve therapie kregen en de dieren die chirurgisch werden behandeld vóór de leeftijd van twaalf maanden, hadden significant meer kans op een succesvolle correctie dan oudere veulens. Verder hadden gevallen met een onvolledige correctie van de hoefconformatie beduidend meer kans op (persisterende) kreupelheid en minder uitzicht op een sportieve carrière. Tot slot bleek uit deze studie een significante associatie tussen de hoefconformatie van het moederdier en die van haar veulens.

\section{INTRODUCTION}

Flexural deformity of the distal interphalangeal joint in horses can occur congenitally or can be acquired later in life (Figure 2A). The latter presentation, usually seen unilaterally in the forelimb at the age of six weeks to six months (Adams and Santschi, 2000; Greet, 2000; Greet and Curtis, 2003) is associated with lateralization. In other words, horses showing a preference to consistently protract the same forelimb during foraging, which may be seen more frequently in foals with relatively long limbs (Van Heel et al., 2006). This posture can lead to an excessive heel growth at the level of the foot placed backwards (Greet, 2000; Spoormakers et al., 2008) and ultimately, to the typical boxy hoof shape, also known as clubfoot (Adams and Santschi, 2000; Greet, 2000; Greet and Curtis; 2003).

As biomechanical loading is a crucial factor during the development of a foal for the quality and resistance of the adult musculoskeletal tissues (Van Weeren et al., 2005) and as hoof shape and limb load- 
ing are linked (Oosterlinck et al., 2011), contralateral hoof asymmetry early in life may cause a reduced athletic capacity and a predisposition for overload injuries (Baxter et al., 2011). Uneven hooves have been shown to have moderate heritability (Ducro et al., 2009a) and dramatically reduce the competitive life of sport horses, especially in elite jumping (Ducro et al., 2009b).

Treatment of acquired flexural deformity of the distal interphalangeal joint can involve trimming and shoeing, medical treatment and/or surgical approaches. Mild cases of clubfoot (hoof-ground-angle less than $90^{\circ}$ ) (Adams and Santschi, 2000) can be resolved by frequently trimming the heel, thus stretching the musculotendinous unit (Greet, 2000). It is essential to keep in mind that excessive trimming of the heel could cause lamellar separation (Redden, 2003). Besides trimming of the heel, glue-on shoes or a toecomposite serving both as protection and extension of the toe, can be a part of the treatment (Auer et al., 2006; Greet, 2000; O'Grady, 2012).

When after trimming, the horse is painful or when the heels are not making contact with the ground, it might be necessary to temporarily elevate the heel by a wedge until the horse is comfortable (Floyd, 2007).

Secondly, analgesia should always be included in the treatment, since pain is a factor that contributes to the contraction of the deep digital flexor tendon (DDFT) (Kidd and Barr, 2002). Furthermore, oxytetracycline can be used as an additional treatment to facilitate the muscle and tendon relaxation (Hunt, 2011), although this may be most successful in neonates (Arnoczky et al., 2004).

In more severe cases (hoof-ground angle greater than $90^{\circ}$ ) or cases not responding to conservative treatment, surgical intervention should be considered (Adams and Santschi, 2000). Most often, desmotomy of the accessory ligament of the deep digital flexor tendon (AL-DFFT) is performed. This can be accomplished by a standard open approach (Auer, 2006), or by a minimal invasive approach (Tnibar, 2010). Severely affected patients with a hoof-ground angle of $115^{\circ}$ or greater, may require more drastic measures such as deep digital flexor tenotomy, usually precluding a future sport career (Adams and Santschi, 2000). Similar to what was described for the non-surgical approach, surgical treatment should be combined with analgesia, correction of the hoof conformation and if necessary, protection of the toe (Auer et al., 2006).

If adequate treatment is delayed, several complications may arise. Severe hoof wall deformation, such as contracted heels, can occur and the increased pressure on the toe may lead to bruising, necrosis and secondary infection. Moreover, the abnormal pressure distribution at the level of the apex of the third phalanx may result in modelling, lipping and/or bone demineralization (Redden, 2003).

The aim of this retrospective study is to report the long-term outcome after surgical and non-surgical treatment of unilateral acquired flexural deformity of

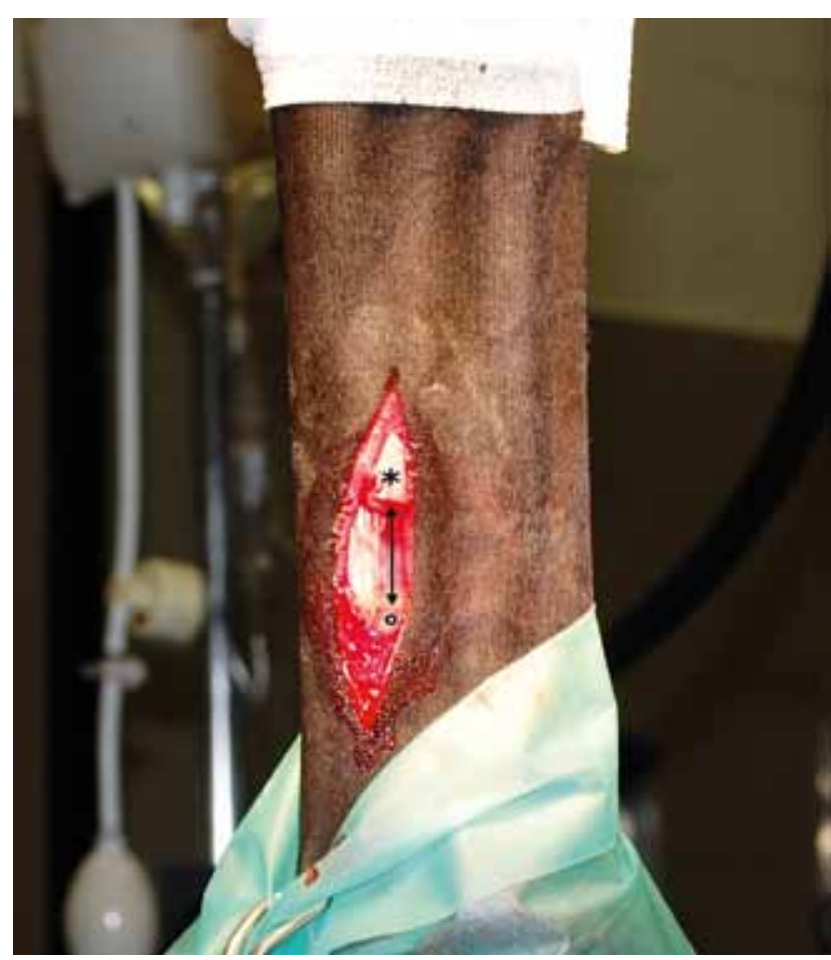

Figure 1. Peroperative image of a desmectomy of the AL-DDFT (* distal and ${ }^{\circ}$ proximal part of the $\mathrm{AL}$ DDFT, $\leftrightarrow$ : gap).

the distal interphalangeal joint, with special attention to functional and cosmetic aspects, and the possible heritability of this condition.

\section{MATERIALS AND METHODS}

\section{Cases}

This study included medical records of patients with acquired flexural deformity of the distal interphalangeal joint, presented to the Faculty of Veterinary Medicine of Ghent University, between January 1999 and December 2013.

Relevant information retrieved from the medical records included: current age and age at admission, gender, breed, clinical and (if available) radiographic findings, diagnosis and treatment. Exclusion criteria were bilaterally affected cases and patients younger than three weeks.

The patients were divided into age groups (younger versus older than six months; younger and older than twelve months). This classification was based on a previous study evaluating the outcome of distal check ligament desmotomy (Wagner et al., 1985).

\section{Treatment}

The cases were divided into a conservatively and a surgically treated group. In the authors' institution, the choice for a conservative versus a surgical approach has always depended on the severity of the deformity, the response to previous conservative management (if 
applicable) and finally, the owner's agreement with the treatment plan.

As described in the introduction, conservative treatment included trimming of the heels, protection of the toe or reconstruction and analgesic medication.

In all but two cases, surgical treatment consisted of a desmectomy (= removal of a $2 \mathrm{~cm}$ portion) of the AL-DDFT under general anesthesia (Figure 1), which would give a slower fibroplasia and thus allow more time for correction of the conformation (Eliashar, 2005). In two cases, a DDFT tenotomy was performed. In one of these cases, the tenotomy was performed at the level of the pastern, whereas the second one was accomplished mid-metacarpus.

The postoperative treatment consisted of trimming of the heels and, if necessary, application of toe protection (Figure 2B). Furthermore, non-steroidal, antiinflammatory drugs (mostly flunixin meglumin) were administered for an average time of five days (median 4 ; range 1-8). The incision was protected by a bandage during 14 days.

\section{Follow-up}

Follow-up was done by telephone questionnaire. This included questions regarding the evolution of the hoof conformation, the horse's gait after treatment, and in surgical cases, the healing of the incision. Secondly, information was obtained regarding the athletic performance of the horse after treatment and, if applicable, its competition level. Horses were considered to have an athletic career if they were performing at national or international level.

Furthermore, information was acquired on the hoof conformation of the dam and her progeny (pluriparous dams).

\section{Statistical analysis}

Data were collected and prepared for analysis using Microsoft Office Excel 2008. Statistical analysis was done with Instat Software (Instat3, Graphpad, La
Jolla, CA, USA) with statistical significance set at $\mathrm{P}$ $<0.05$.

The associations between the outcome and the age on presentation (before versus after six months, before versus after twelve months), the outcome and the type of treatment (conservative versus surgical), the conformation and presence of lameness and the conformation of the patient and the dam were examined using Fisher's Exact test. Shapiro-Wilk test, Q-Q plots and Kolmogorov-Smirnov test were used to evaluate whether or not data showed significant deviation from normal distribution. Normally distributed data are presented as mean \pm standard deviation (SD), while non-parametric data are presented as median [range].

\section{RESULTS}

\section{Case details}

Fifty-one cases were included in this study (29 mares and 22 stallions), with a median age at admission of four months (range 1-58 months). The majority were warmbloods $(46 / 51)$. Forty-four cases were twelve months of age or younger (median age four months, range 1-12 months) and seven were older (median age 22 months, range 14-58 months).

Sixty-three percent of the cases (32/51) were diagnosed with a flexural deformity at the level of the right forelimb. Twenty-six of all cases $(51 \%)$ were treated conservatively and in 25 cases (49\%), surgery was the treatment of choice.

\section{Outcome}

Follow-up information was available for all cases included in this study. The mean duration of follow-up was seven years (range 9-168 months). In Table 1, the most important outcome variables are summarized.

Overall, there was a high degree of client satisfaction after treatment. Based on the telephone questionnaire, $21 / 26(81 \%)$ of the owners of the conserva-

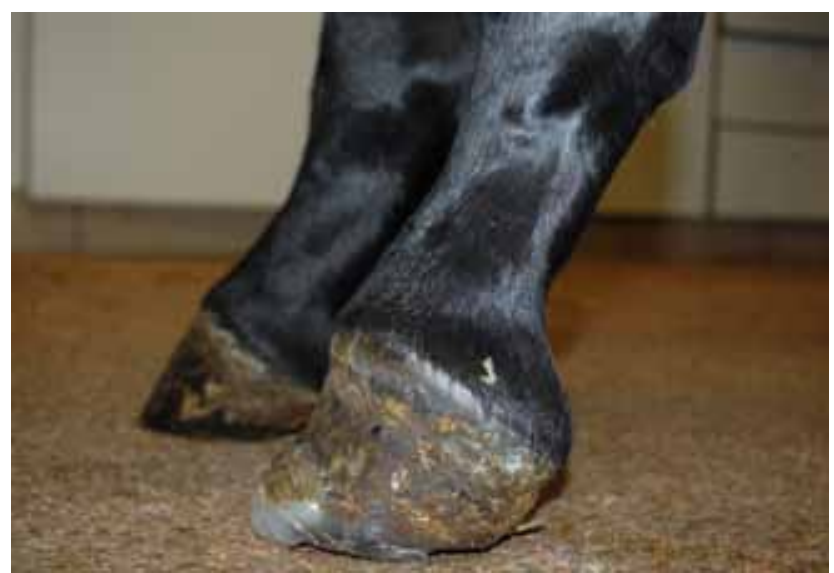

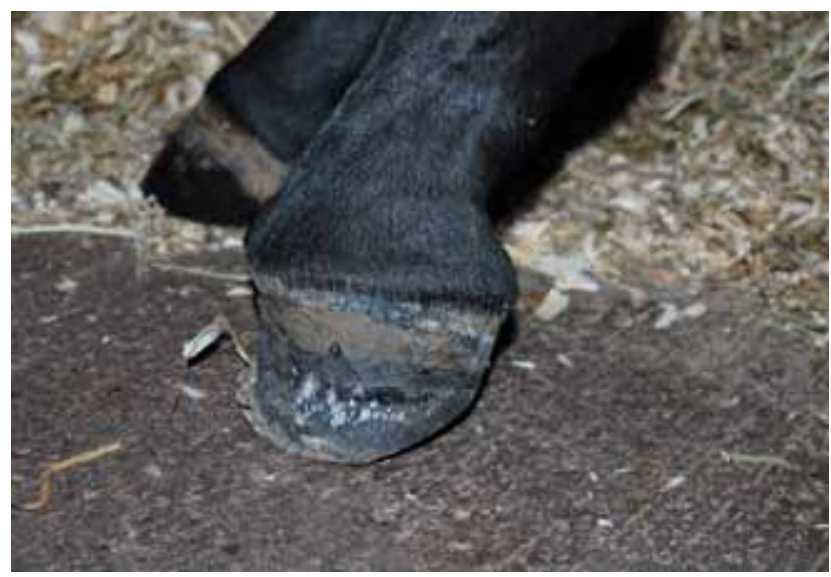

Figure 2. Even in severe cases of flexural deformity of the distal interphalangeal joint (A), correction of hoof conformation a few days after desmotomy of the AL-DDFT can be achieved (in this picture, combined with an extension and reconstruction of the toe with composite (Superfast ${ }^{\mathrm{TM}}$, Vettec, USA) (B). 
tively treated patients and 19/25 (76\%) of the surgically treated cases were satisfied with the outcome, resulting in an overall satisfaction rate of $78 \%(40 / 51)$.

\section{Conservative treatment}

Based on the information provided by the owners, $65 \%(17 / 26)$ of the conservatively treated patients had a complete correction of hoof conformation. There was a significant association between the correction of hoof conformation and the age of the foal at the time of treatment $(\mathrm{P}=0.035)$. A foal was nearly 13 times more likely to obtain complete correction of hoof conformation when treated before six months of age than after six months of age (odds ratio (OR) 12.80; 95\% confidence interval (CI) 1.15-142.66). However, when comparing the groups $\leq$ twelve months versus $>$ twelve months of age, there was no significant association between the age of treatment and the correction obtained. Three of the nine patients with incomplete correction of hoof conformation were older cases; two of them were even older than four years when admitted at the clinic.

Owners declared $81 \%$ of the conservatively treated patients $(21 / 26)$ to be sound. Lameness was significantly associated with the correction of hoof conformation $(\mathrm{P}=0.0019)$. Horses with incomplete hoof correction were 43 times more likely to develop lameness (OR 42.78; 95\%CI 1.98-926.67).

At the moment of the questionnaire, 18 of the conservatively treated horses had reached the age to perform (minimum age of three years old). Fourteen of them $(78 \%)$ were used as a riding horse, $71 \%$ of which (10 horses) were performing at national or international level. The group of riding horses included all of the cases with a fully corrected conformation (10 horses) and four of the eight cases $(50 \%)$ with incomplete correction. The other four horses with incomplete correction of their hoof conformation did not seem fit to ride and were merely kept on pasture.

\section{Surgical treatment}

According to the owners, 14 of the 25 surgically treated cases (56\%) achieved full correction of hoof conformation, which is not significantly different from the conservatively treated cases $(\mathrm{P}=0.5725)$. There was a significant association between the degree of correction and the age at the time of treatment ( $\leq$ twelve months versus $>$ twelve months) $(\mathrm{P}=0.026)$. Patients undergoing surgery $\leq$ twelve months of age had a 17 times greater chance of full correction of hoof conformation (OR 17.40; 95\%CI 0.82-368.36) than those undergoing surgery at a later age. However, this association was not present when comparing foals that underwent surgery at $\leq$ six months versus $>$ six months of age.

Although complete correction of hoof conformation was not always achieved after surgery, $72 \%$ of the horses $(18 / 25)$ were considered sound by the owner. In two of the lame horses, a DDFT-tenotomy had been performed, one of which was previously treated with a desmectomy of the AL-DDFT. There was a significant association between the correction of hoof conformation and the presence of lameness $(\mathrm{P}=0.0213)$. Horses without full correction of hoof conformation were 16 times more likely to develop lameness (OR $15.60 ; 95 \%$ CI 1.48-164.47).

Also in the surgically treated group, 17 horses had reached the age to perform at the moment of the questionnaire. Fifteen of them (88\%) were used as a riding horse, including all horses with a fully corrected hoof conformation (eleven horses) and four of the six horses $(67 \%)$ with an incomplete correction. Ten of these 15 riding horses $(67 \%)$ were performing at a national or international competitive level, the vast majority of which $(8 / 10)$ presented a fully corrected hoof conformation. Two horses were not considered fit for riding; one of them had been treated with a DDFT-tenotomy and one horse was eliminated at high-level endurance, although it is unknown if this was actually due to the slightly steeper foot.

No serious problems were encountered with wound healing related to the desmectomy. Nevertheless, residual swelling $(9 / 23)$, a scar $(2 / 23)$ or white discoloration of hairs $(3 / 23)$ were observed, resulting in cosmetic flaws in about $50 \%$ of the horses. There was no significant association between the formation of scar tissue and age.

\section{Damline and progeny}

Based on the information provided by the owners, $20 \%(10 / 51)$ of the patients had a dam with a contralateral hoof asymmetry.

In $27 \%(11 / 42)$ of pluriparous dams in this study, the mare had given birth to several other foals that developed a flexural deformity of the distal interphalangeal joint. In the sample of pluriparous dams, there was a significant association between the presence of hoof unevenness in the dam and in her progeny ( $\mathrm{P}$ $=0.0028$ ). Foals from a dam with clubfoot had a 25 times greater chance to develop a clubfoot than foals from a dam with a normal hoof conformation (OR 25.00; 95\%CI 2.46-254.30).

\section{DISCUSSION}

This retrospective study included 51 cases treated for acquired flexural deformity of the distal interphalangeal joint. Most of the horses presented acquired flexural deformity of the right forelimb, which is in agreement with the observation that most non-ambidextrous horses have a preference to protract the left limb (Warren-Smith and McGreevy, 20120).

A similar proportion of the cases were treated sur- 
Table 1. Most important outcome parameters for the two different treatments. No statistical associations were found between the type of treatment and the outcome.

\begin{tabular}{lccc}
\hline & Conservative & Surgical & P-value \\
\hline Correct hoof conformation & $17 / 26$ & $14 / 25$ & 0.5725 \\
& $(65 \%)$ & $(56 \%)$ & \\
Absence of lameness & $21 / 26$ & $18 / 25$ & 0.5230 \\
& $(81 \%)$ & $(72 \%)$ & \\
Riding horses (horses > 3 yrs old) & $14 / 18$ & $15 / 17$ & 0.6581 \\
& $(78 \%)$ & $(88 \%)$ & \\
Riding horses used for (inter)national competition & $10 / 14$ & $10 / 15$ & 1.000 \\
& $(71 \%)$ & $(67 \%)$ & \\
Owner satisfaction & $21 / 26$ & $19 / 25$ & 0.7432 \\
& $(81 \%)$ & $(76 \%)$ & \\
\hline
\end{tabular}

gically and non-surgically, and long-term follow-up was obtained by telephone questionnaire. The success rate for the surgical and the non-surgical correction of the abnormal hoof conformation was moderate $(56 \%$ and $65 \%$, respectively). However, the functional success was higher as there were also horses with incomplete correction that were sound and/or were used as a riding horse. Based on the results of the present study, the prognosis for competition seems good when full correction of hoof conformation can be achieved. About two thirds of the riding horses were able to compete, whereas it must be noted that some horses may not be in competition for reasons other than poor response to treatment of the flexural deformity. Last but not least, with an overall satisfaction rate of $78 \%$, both the results of the conservative and the surgical treatment were highly appreciated by the owners.

Clearly, it was not the primary goal of this study to directly compare the success rates of the surgical and non-surgical treatment since in a retrospective study, treatment cannot be organized randomly but is tailored to each individual case according to its history and the severity of the deformity.

As a limitation of the study, no objective measurements were performed to quantify the severity of the deformity and the degree of correction, which can have a certain influence on the outcome results. It can be assumed that mild cases were treated conservatively, whereas more severe cases or cases not responding to conservative treatment, were treated surgically. Nevertheless, there was no significant difference in outcome between the two types of treatment.

The results of the present study show that the age of the patient, and thus the chronicity of the deformity, significantly affects the success of treatment. In patients treated non-surgically, conservative management at an age $\leq$ six months results in a better prognosis than in older patients. In the surgically treated group, the window of opportunity for treatment is wider, with significantly better results in patients treated $\leq$ twelve months than in older horses. These findings should encourage veterinarians, farriers and owners not to delay treatment after a flexural deformity of the distal interphalangeal joint has been diagnosed. Especially the non-surgical treatment should be performed early enough ( $<$ six months), whereas there seems to be a bit more time to perform surgical treatment, provided that no complications, such as contracted heels, develop. Although the success rate has been reported to decrease with increasing duration of symptoms, some chronic cases can still be treated successfully (Yiannikouris et al., 2011).

Achieving full correction is important and the results of the present study are in agreement with other studies stating that persisting contra-lateral hoof unevenness is associated with lameness (Baxter et al., 2011; Ross and Dyson, 2003). Furthermore, Oosterlinck et al. (2011) demonstrated that even in clinically sound ponies with symmetrical hooves, a hoof with a smaller contact area (e.g. a more upright hoof with contracted heels and a concave sole) is loaded less compared to a hoof with a larger contact area (e.g. hoof with low, spread heels and a flat sole).

Cosmetic healing of the wound was not perfect in about $50 \%$ of the surgically treated cases. Although low numbers precluded statistical analysis, suture material may play a role herein. All horses with a continuous polyglyconate monofilament Maxon $^{\mathrm{TM}}$, Covidien, Ireland) suture had a perfect cosmetic outcome whereas at least six cases closed with a continuous polyglactin 910 (Vicryl ${ }^{\mathrm{TM}}$, Ethicon) suture presented residual swelling at the moment of the questionnaire.

This study showed that there was a significant association between the development of flexural deformity of the distal interphalangeal joint of the dam and her progeny. Although this finding in a sample of 42 (pluriparous) cases needs to be confirmed in larger studies, the hereditary aspect may influence breeding policies. The observed association is in agreement with the study of Ducro (2009a), which showed 
a moderate but significant heritability of heel height and hoof shape. Furthermore, it has been demonstrated that horses with a small head and relatively long legs, would be more prone to develop uneven feet (Van Heel et al., 2006). This conformation is dominantly present amongst modern warmblood foals.

\section{CONCLUSION}

The results of the present study show that conservative treatment performed before the age of six months and surgical treatment performed before the age of twelve months result in the best chance for complete correction of a clubfoot. Furthermore, a significant association was found between the degree of correction and the soundness of the horse at later age. With an overall satisfaction rate of $78 \%$, both the conservative and the surgical treatment were highly appreciated by the owners and both treatments resulted in a similarly high proportion of riding horses that were able to compete (around 70\%). For breeders, it is important to realize that flexural deformity of the distal interphalangeal joint seems to be heritable by the damline at least.

\section{REFERENCES}

Adams S.B., Santschi E.M. (2000). Management of congenital and acquired limb deformities. In: Proceedings of the $46^{\text {th }}$ Annual convention of the American Association of Equine Practitioners (2000), 117-125

Arnoczky S.P., Lavagnino M., Gardner K.L., Tian T., Vaupel Z.M., Stick J.A. (2004). In vitro effects of oxytetracycline on matrix metalloproteinase-1 mRNA expression and on collagen gel contraction by cultured myofibroblasts obtained from the accessory ligament of foals. American Journal of Veterinary Research 65, 491-496

Auer. J.A. (2006). Diagnosis and treatment of flexural limb deformities in foals. Clinical Techniques in Equine Practice 5, 282-295

Baxter G.M., Stashak T.S., Hill C. (2011). Conformation and movement. In: Baxter G.M. (editor). Adams and Stashak's Lameness in Horses. 6th Edition, Wiley-Blackwell, Philadelphia, 73-108

Ducro B.J., Bovenhuis H., Back W. (2009a). Heritability of foot conformation and its relationship to sports performance in a Dutch Warmblood horse population. Equine Veterinary Journal 41, 139-143

Ducro B.J., Gorissen B., Van Eldik P., Back W. (2009b). Influence of foot conformation on duration of competitive life in a Dutch Warmblood horse population. Equine Veterinary Journal 41, 144-148

Eliashar E., Dyson S.J., Archer R.M., Singer E.R., Smith R.K.W. (2005). Two clinical manifestations of desmopathy of the accessory ligament of the deep digital flexor tendon in the hindlimb of 23 horses. Equine Veterinary Journal 37, 495-500

Floyd A. E. (2007). Deformities of the limb and their relevance to the foot. In: Floyd A.E., Mansmann R.A. (editors). Equine Podiatry. Elsevier Saunders, Philadelphia, 205-223
Greet T.R.C. (2000). Managing flexural and angular limb deformities: a newmarket perspective. In: Proceedings of the $46^{\text {th }}$ Annual convention of the American Association of Equine Practitioners (2000), 130-136

Greet T.R.C., Curtis S.J. (2003). Foot management in the foal and weanling. Veterinary Clinics of North America: Equine Practice 19, 501-517

Hunt R.J. (2011). Flexural limb deformities in foals. In: Ross M.W., Dyson S.J. (editors). Diagnosis and Management of Lameness in the Horse. W.B. Saunders, Philadelphia, 645-649

Kidd J.A., Barr A.R.S. (2002). Flexural deformities in foals. Equine Veterinary Education 14, 311-321

Medland S.E., Duffy D.L., Wright M.J., Geffen G.M., Hay D.A., Levy F., Van-Beijsterveldt C.E.M., Willemsen G., Townsend G.C., White V., Hewitt A.W., Mackey D.A., Bailey J.M., Slutske W.S., Nyholt D.R., Treloar S.A., Martin N.G. Boomsma D.I. (2009). Genetic influences on handedness: Data from 25,732 Australian and Dutch twin families. Neuropsychologia 47, 330-337

O'Grady S.E. (2012). Flexural deformities of the distal interphalangeal joint (clubfeet). Equine Veterinary Education 24, 260-268

Oosterlinck M., Pille F., Back W., Dewulf J., Gasthuys F. (2011). A pressure plate study on fore and hindlimb loading and the association with hoof contact area in sound ponies at the walk and trot. The Veterinary Journal 190, 71-76

Redden R. F. (2003). Hoof capsule distortion: understanding the mechanisms as a basis for rational management. Veterinary Clinics of North America: Equine Practice 19, 443-462

Ross M.W., Dyson S.J. (2003). The foot and shoeing. In: Ross M.W., Dyson S.J. (editors). Diagnosis and Management of Lameness in the Horse. 1st Edition, W.B. Saunders, St.-Louis, 250-275

Spoormakers T.J.P., de Vries A., van Muiswinkel K., ter Braake F. (2008). Flexural deformity of the distal interphalangeal joint in the horse: results of 53 desmotomies in 40 foals. Vlaams Diergeneeskundig Tijdschrift 77, 299-306

Tnibar A. (2010). Desmotomy of the accessory ligament of the deep digital flexor tendon in horses: an update. Journal of Equine Veterinary Science 30, 715-719

Yiannikouris S., Schneider R., Sampson S., Roberts G. (2011). Desmotomy of the accessory ligament of the deep digital flexor tendon in the forelimbs of 24 horses 2 years and older. Veterinary Surgery 40, 272-276

Van Heel M.C., Kroekenstoel A.M., van Dierendonck M.C., van Weeren P.R., Back W. (2006). Uneven feet in a foal may develop as a consequence of lateral grazing behaviour induced by conformational traits. Equine Veterinary Journal 38, 646-651

Van Weeren P.R., Firth E.C., Brama P.A.J. (2010). To move or to perish: the importance of exercise during musculoskeletal development. Pferdeheilkunde 26, 581-587

Wagner P.C., Grant B.D., Kaneps A.J., Watrous B.J. (1985). Long-term results of desmotomy of the accessory ligament of the deep digital flexor tendon (distal check ligament) in horses. Journal of the American Veterinary Medical Association 187 (12), 1351-1353

Warren-Smith A., McGreevy P. (2010). The use of pedometers to estimate motor laterality in grazing horses. Journal of Veterinary Behaviour 5, 177-179 